\title{
Regulation of shoot-system development in Populus
}

\author{
Amy Brunner ${ }^{1 *}$, Xiaoyan Sheng ${ }^{1}$, Joesph Edwards' ${ }^{1}$ Takeshi Fujino ${ }^{1}$, Chieh-Ting Wang ${ }^{1}$, Stephen DiFazio ${ }^{2}$ \\ From IUFRO Tree Biotechnology Conference 2011: From Genomes to Integration and Delivery \\ Arraial d'Ajuda, Bahia, Brazil. 26 June - 2 July 2011
}

Shoot phenology interacts with crown morphology to determine leaf production and duration over the growing season and throughout a tree's life span; and thus, this interaction has a major role in determining whole-tree photosynthesis and biomass yield. For several years, the pattern of shoot meristem activity determines Populus crown architecture, but after the first onset of flowering the specification of meristem identity (inflorescence vs. vegetative) also has a major influence on crown form. To study how shoot meristem activity and identity are regulated in Populus, we are focusing on two pathways that have been extensively characterized in annual plants: 1 ) the MORE AXILLARY BRANCHING (MAX) genes that are involved in the synthesis and perception of upwardly mobile strigolactones that inhibit axillary bud outgrowth, and 2) members of the TERMINAL FLOWER1 (TFL1)/ FLOWERING LOCUS T (FT) and APETALA1(AP1)/ FRUITFULL(FUL) gene families that regulate flowering. We are taking a multi-pronged approach that includes field and controlled-environment study of poplar transgenics, transcriptome analyses, cell-specific expression studies, and QTL and association mapping.

QTL mapping in a hybrid poplar pedigree localized three of seven poplar $M A X$ genes in QTL for bud set and two $M A X$ genes in sylleptic branching QTL. All $M A X$ transgenics were established in a field trial and phenotyping of phenology, crown morphology, and growth is in progress. Greenhouse studies of poplar transgenics with the seven different poplar MAX gene promoters driving the reporter gene GUS show that most of the $M A X$ genes are expressed in vascular tissues. However, vascular expression patterns are different, especially in stems undergoing secondary growth. Surprisingly, none of the

\footnotetext{
* Correspondence: abrunner@vt.edu

${ }^{1}$ Department of Forest Resources and Environmental Conservation, Virginia Tech, Blacksburg, VA 24061, USA

Full list of author information is available at the end of the article
}

RNAi transgenics showed differences in branching in the greenhouse under standard growing conditions. High nitrogen levels can induce sylleptic branching in poplar and greenhouse experiments with $M A X$ transgenics indicate a possible role for one $M A X$ gene in nitrogeninduced sylleptic branching. Ongoing studies of the effects of decapitation of the shoot apex with and without subsequent auxin application to the cut stem indicate that, as predicted based on studies in annual plants, the poplar MAX RNAi transgenics show a reduced response to apically-applied auxin.

Recent work has revealed that poplar FT1 and FT2 have diverged in regulation and function with FT1 promoting the transition to flowering in response to winter temperatures, whereas warm temperatures and long days promote $F T 2$ expression and shoot growth [1]. In Arabidopsis, $F T$ activates $A P 1$, a key regulator of flower initiation. Expression and transgenic studies in poplar indicate that similar to the two poplar FTs, poplar AP1 subfamily members have roles in both flowering and bud set in response to short-days and abiotic stress. Ongoing work is aimed at defining the roles of $F T$ and AP1 modules in these processes and to delineate the roles of the five different poplar AP1/FUL genes. Finally, TFL1 acts opposite to $F T$ to promote vegetative meristem identity in Arabidopsis, and AP1 and TFL1 repress each other's expression. The poplar TFL1 homologs, CEN1 and/or CEN2 have roles in maintaining vegetative identity and in the dormancy-growth transition [2] and we are currently working to define the individual roles of the poplar CENs and their relationships to $F T$ and $A P 1$ activities.

\footnotetext{
Acknowledgements

This work was supported by National Research Initiative Competitive Grants Program grant \#2008-35301-19167 from the USDA National Institute of Food and Agriculture and the US Department of Energy's Bioenergy Sciences Center.
} 


\section{Author details}

${ }^{1}$ Department of Forest Resources and Environmental Conservation, Virginia

Tech, Blacksburg, VA 24061, USA. ${ }^{2}$ Department of Biology, West Virginia

University, Morgantown, WV 26506, USA.

Published: 13 September 2011

\section{References}

1. Hsu CY, Adams J, Kim H, No K, Ma C, Strauss SH, Drnevich J, Vandervelde L, Ellis JD, Rice M, Wickett N, Gunter LE, Tuskan GA, Brunner AM, Page GP, Barakat A, Carlson JE, dePamphilis C, Luthe DS, Yuceer MC: FLOWERING LOCUS $T$ duplication coordinates reproductive and vegetative growth in perennial poplar. PNAS 2011.

2. Mohamed R, Wang CT, Ma C, Shevchenko O, Dye SJ, Puzey JR,

Etherington E, Sheng X, Meilan R, Strauss SH, Brunner AM: Populus CEN/ TFL1 regulates first onset of flowering, axillary meristem identity and dormancy release in Populus. Plant J 2010, 62:674-688.

doi:10.1186/1753-6561-5-S7-I11

Cite this article as: Brunner et al:: Regulation of shoot-system development in Populus. BMC Proceedings 2011 5(Suppl 7):111.

\section{Submit your next manuscript to BioMed Central} and take full advantage of:

- Convenient online submission

- Thorough peer review

- No space constraints or color figure charges

- Immediate publication on acceptance

- Inclusion in PubMed, CAS, Scopus and Google Scholar

- Research which is freely available for redistribution

Submit your manuscript at www.biomedcentral.com/submit 